\title{
Petroleum hydrocarbons in a water-sediment system from Yellow River estuary and adjacent coastal area, China: Distribution pattern, risk assessment and sources
}

\author{
Min Wang ${ }^{\mathrm{a}}$, Chuanyuan Wang ${ }^{\mathrm{b}, *}$, Yuanwei $\mathrm{Li}^{\mathrm{b}}$ \\ a Management Science and Engineering Institute, Shandong Institute of Business and Technology, Yantai 264025, China \\ ${ }^{\mathrm{b}}$ Key Laboratory of Coastal Zone Environmental Processes, Yantai Institute of Coastal Zone Research, Chinese Academy of Sciences, Yantai 264003, China
}

\section{A R T I C L E I N F O}

\section{Keywords:}

Spatial variation

Seasonal variations

Petroleum hydrocarbon

Biomarker

Water-sediment system

Yellow River Delta

\begin{abstract}
A B S T R A C T
Aliphatic hydrocarbons (AHs), biomarker and polycyclic aromatic hydrocarbons (PAHs) concentrations of surface water and sediment samples collected from Yellow River Estuary and adjacent coastal area in China were measured to determine their spatial distributions, analyze their sources and evaluate the ecological risk of PAHs in the water-sediment system. The spatial distributions of $n$-alkane in sediments are mainly controlled by the mixing inputs of terrigenous and marine components. In comparison with AHs, the total concentrations of $\Sigma 16$ PAHs in surface sediments from a transect of the offshore area were noticeably higher than that of the riverine and estuary areas. Additionally, the AHs and total PAHs concentrations all indicated an overall pattern of a seaward decrease. The PAHs concentrations during the dry season (mainly in the form of dissolved phase) were higher than that of PAHs (mainly dissolved phase and particulate phase form) in the flooding season. In comparison with global concentration levels of PAHs, the level of PAHs in suspended particulate matter and sediments from the Yellow River Estuary was lower than those from other countries, while the concentration of PAHs in the dissolved phase were in the middle range. Petroleum contamination, mainly from oil exploration and discharge of pollutants from rivers, was the main source of $n$-alkanes. The PAHs in the river were mostly of petrogenic origin, while those in the estuarial and marine areas originated mainly from pyrogenic sources. The results of the toxicology assessment suggested that the PAHs in sediments from Yellow River Estuary and adjacent coastal area exhibited a low potential eco-toxicological contamination level.
\end{abstract}

\section{Introduction}

Organic pollution from anthropogenic sources to aquatic environments is becoming increasingly concerning. Among the organic contaminants, aliphatic hydrocarbons (AHs) and polycyclic aromatic hydrocarbons (PAHs) have been widely recognized as common organic contaminants that may impact the health of ecosystems and humans. They can enter river or coastal zone environments via direct discharge, surface run-off, atmospheric deposition and biogenic inputs. More importantly, concern has focused on PAHs due to their toxicity, mutagenicity and carcinogenicity (Malik et al., 2011; Yuan et al., 2014). For the reasons above, $16 \mathrm{PAH}$ compounds have been classified as priority pollutants by the United States Environmental Protection Agency (US EPA) and the European Union due to their potential threat to ecosystems and humans (Hu et al., 2010). Owing to their physicochemical properties, PAHs in aquatic systems exist in several phases, including the free dissolved phase, dissolved organic matter (DOM) bound, adsorbed suspended particulate matter (SPM) and surface sediments. SPM may be generated from the re-suspension of the sediment. As a result, SPM plays an important role in the transportation of PAHs in aquatic multimedia. In general, PAHs come mainly from two sources: petrogenic and pyrogenic. Apart from the combustion source, another common anthropogenic source of PAHs is the accidental spillage of fossil fuels.

Estuaries and coastal zones are a transitional zone between land and ocean systems. Therefore, the physical and chemical changes are more extreme in estuary environments than in many other environments as a result of tides, river flow and dry-wet cycles. As the second largest river in China and sixth largest river in the world, the Yellow River carries a huge amount of sediments to the Bohai Sea when flowing through the Loess Plateau, China. The Yellow River Delta (YRD), one of the most active regions of land-ocean interaction among the large river deltas in the world, is a newly born wetland in China. Estuaries often act as sinks for sediments and the associated particle-reactive contaminants; thus,

\footnotetext{
* Corresponding author.

E-mail address: cywang@yic.ac.cn (C. Wang).
} 
AHs and PAHs from the upper reaches of the Yellow River may have been transported to the estuaries by solids or water before accumulating at the estuary mouth. The YRD is the main sink of organic pollutants discharged from the Yellow River watershed. Rapid economic growth in YRD raises concerns of significant oil pollution to aquatic environment and sediment. Additionally, the increased exploitation of the nearby Shengli Oilfield, the second largest oilfield in China, probably resulted in local petroleum hydrocarbon contamination in the area. Thus, the investigation of AHs and PAHs in the water-sediment system of estuaries and coastal zone areas may help elucidate the balance between inputs and losses and further our understanding of the associated environmental processes and outcomes.

Protecting the delicate ecology in the YRD is of great importance. There have been several studies on AHs and PAHs in marine sediments, such as distribution, source apportionment of PAHs in estuarine sediments from the Yellow River (Liu et al., 2008), hydrocarbons in the surface sediments from the Huanghe Estuary and adjacent area (Zhang et al., 2010) or distribution, source apportionment and potential toxicological significance of AHs and PAHs in Yellow River Delta wetlands (Yang et al., 2009; Wang et al., 2011; Yuan et al., 2014) from the YRD, sources appointment and ecological risk assessment of PAHs in sediments of Erhai Lake, China (Hezhong et al., 2016). They indicate that sedimentary AHs and PAHs are at low or medium levels compared with the reported values of other deltas, and are derived from mixed pyrogenic and petrogenic sources. However, to the best of our knowledge, detailed information on the spatial-temporal distribution and ecological risk evaluation of the distribution of AHs and PAHs in the Yellow River Estuary (YRE) remains scarcely documented; especially with respect to the water-sediment system encompassing the marine, estuarine and lower estuarine regions. The aims of this study were to (1) determine the spatial-temporal distributions of AHs, biomarkers and PAHs in the water-sediment system from the Yellow River encompassing the riverine, estuarine and offshore areas; (2) examine the potential input sources of petroleum hydrocarbons and analyze the source apportionment of PAHs in the sediment-water system; and (3) assess the potential eco-toxicological consequences on organisms in the region.

\section{Materials and methods}

\subsection{Sampling location}

The surface sediments used were collected from the YRD and adjacent coastal area in November 2012 (Fig. 1). The collecting period avoided the high rainfall season. Lijin Hydrographic Station is the last hydrographic station of the Yellow River. The sampling stations were arranged along a $127.5 \mathrm{~km}$ stretch from the Lijin Hydrological Stations to the river mouth along the Yellow River, extending from the lower stretch estuary (R1-R8) to the main estuary (Est-1-Est-5) and the offshore area of Bohai Sea with the transect (T-B; Table 1). Est-1 station is Xintan Oilfield Floating Bridge, which is regarded as the Yellow River
Entrance. Sampling sites used in this study commenced from the freshwater end-member in the upper reaches of the river estuaries to the saltwater sea and encompassed the entire salinity gradient. The surface sediments $(0-5 \mathrm{~cm})$ were collected using a Van Veen style stainless steel grab sampler ( $24 \mathrm{~L}$ ) manufactured by the Wildlife Supply Company. Following collection, the samples were homogenized, placed into sterile polyethylene bags, sealed and stored at $-4{ }^{\circ} \mathrm{C}$ until further analysis. The concurrent sampling of the surface water $(0.5 \mathrm{~m}$ depth) from the 4 sites (R6, R8, Est.-2, T-B5) were also collected in May (Flooding season) and November (Dry season) 2012. Twenty liters of water was collected from each sampling site. $100 \mathrm{mg} / \mathrm{L} \mathrm{HgCl}_{2}$ was added to each water sample container for the inhibition of bacterial growth during transportation and temporary storage. Then transported on ice to the laboratory, where they were stored at $-20^{\circ} \mathrm{C}$ until further analysis.

\subsection{Extraction and fractionation}

The procedures for eluting dissolved organics from XAD resins and for processing glass fiber filters have been described extensively elsewhere (Sun et al., 2009). Briefly, after back to the laboratory, SPMs were collected by filtering the water samples through GF/F glass fiber filters (diameter $0.7 \mathrm{~mm}$, Whatman, UK). The SPM samples filtered through the glass fiber filter were freeze-dried and weighed using an analytical balance. The filtered water was then passed through a mixed resin (Sigma Amberlite XAD-4 and XAD-2 1:1 mixtures) glass column ( $400 \mathrm{~mm} \times 25 \mathrm{~mm}$ i.d.) to retain dissolved organics. The XAD resin was transferred into a glass flask and extracted 3 times with 2:1 dichloromethane $/ n$-hexane $(\mathrm{v} / \mathrm{v})$ in an ultrasonic bath, after which the extracts were combined. The fraction drained with anhydrous $\mathrm{Na}_{2} \mathrm{SO}_{4}$ was then concentrated using a rotary evaporator and further evaporated under a nitrogen stream to approximately 1-2 mL. Lastly, the fraction was spiked with surrogate recovery standards (terphenyl-d14) for Gas Chromatography-Mass Spectrometer (GC-MS) analysis.

The sediment samples were freeze-dried, ground and separated with a $125-\mu \mathrm{m}$ sieve to remove large particles and debris in April 2013. The freeze-dried SPM-loaded glass fiber filters and sediment samples were weighed and spiked with surrogate recovery standards (terphenyl-d14) and Soxhlet-extracted for $72 \mathrm{~h}$, with $n$-hexane, toluene, chloroform and methanol as extraction solvent. Elemental sulfur was removed from the extracts using activated copper. The extracts were fractionated by column chromatography on alumina over silica gel. Silica gel and anhydrous sodium sulfate were baked in a furnace oven at $650{ }^{\circ} \mathrm{C}$ for $6 \mathrm{~h}$ prior to use. The fractions of saturated hydrocarbons, aromatic hydrocarbons and non-hydrocarbons were obtained by successively eluting with $n$-hexane, toluene and chloroform/methanol (98:2), respectively. The saturated and aromatic hydrocarbon fractions were concentrated again in a rotary evaporator, transferred to a vial, and then the volume was evaporated to exactly $1 \mathrm{~mL}$ using a stream of filtered $\mathrm{N}_{2}$ gas. An aliquot of $1 \mathrm{~mL}$ of each extract was subjected to analysis by GC-MS.

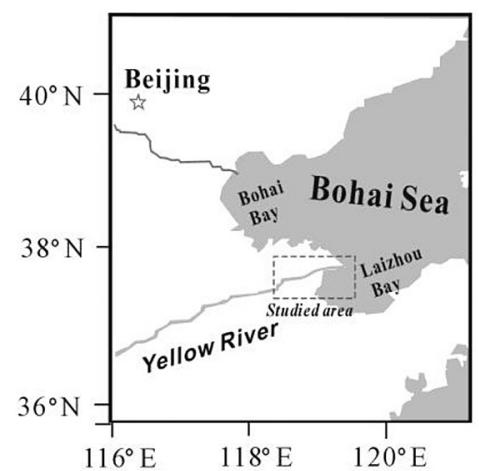

$116^{\circ} \mathrm{E} \quad 118^{\circ} \mathrm{E} \quad 120^{\circ} \mathrm{E}$

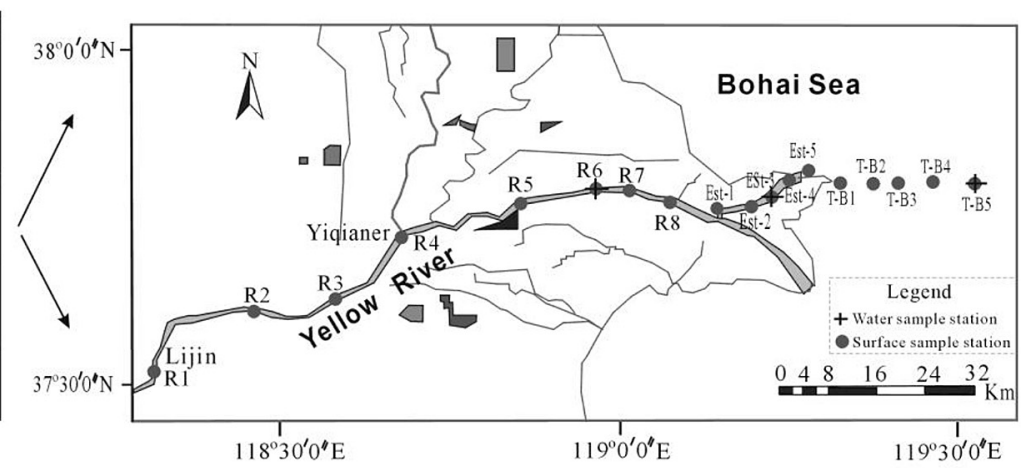

Fig. 1. Study areas and sampling location. 
Table 1

Sample information of sediments from rivers, estuaries and coasts.

\begin{tabular}{|c|c|c|c|c|c|c|c|c|c|c|c|c|c|}
\hline Sample & $\mathrm{R} 1$ & $\mathrm{R} 2$ & R3 & R4 & R5 & R6 & R7 & $\mathrm{R} 8$ & R9 & Est.1 & Est4 & T-B1 & T-B5 \\
\hline Hydrological stations & Lijin & Zhangqiu wuzi & Lianhe & Yiqianer & Qingjia 3 & Qingjia 5 & Qing 7 & Qingjia 9 & Cha 3 & Estuary & & \multicolumn{2}{|c|}{ Marine area } \\
\hline Distance from estuary $(\mathrm{km})$ & 127.5 & 97.5 & 85 & 70 & 47.5 & 37.5 & 30 & 22.5 & 7.5 & 0 & 7.5 & ND & ND \\
\hline Surface water salinity (\%o) & ND & ND & ND & ND & ND & 0.48 & ND & ND & 0.53 & 2.28 & 28.1 & ND & ND \\
\hline
\end{tabular}

Note: ND: not detected.

\subsection{Instrumental analysis}

The sample granulometry was analyzed on fresh sediments using a Malvern Mastersizer 2000 laser diffractometer capable of analyzing particle sizes between 0.02 and $2000 \mu \mathrm{m}$. The freeze-dried sediments were ground in an agate mortar prior to elemental and isotopic analysis. Total carbon (TC) was analyzed via high temperature combustion on an Elementar vario MACRO cube CHNS analyzer. Total inorganic carbon (TIC) analysis was performed using a Shimadzu TOC-VCPH/ SSM-5000A analyzer. Replicate analysis of 1 sample $(n=5)$ gave a $1-\sigma$ precision of $\pm 0.02 \mathrm{wt} \% \mathrm{C}$.

The saturated and aromatic hydrocarbons fractions were analyzed using a Hewlett-Packard 6890 gas chromatograph interfaced with a Hewlett-Packard 5973 mass-selective detector (Agilent Technologies Inc., USA). The samples were analyzed using a fused silica capillary column (30 $\mathrm{m} \times 0.20 \mathrm{~mm} \times 0.25 \mu \mathrm{m}$ film thickness). Helium was the carrier gas at a flow rate of $1 \mathrm{~mL} / \mathrm{min}$. The temperature was programmed from $80{ }^{\circ} \mathrm{C}$ to $290{ }^{\circ} \mathrm{C}$ at $4{ }^{\circ} \mathrm{C} / \mathrm{min}$ and held at the final temperature for $30 \mathrm{~min}$. The injector temperature and transfer line temperature were $250{ }^{\circ} \mathrm{C}$ and $180{ }^{\circ} \mathrm{C}$, respectively. The samples were injected in the splitless mode. The mass spectrometer was operated at an electron energy of $70 \mathrm{eV}$.

Individual $n$-alkanes were identified based on the retention time of the authentic standards $\left(\mathrm{nC}_{10-40}\right.$, Sigma), and concentrations of each $n$ alkane were calculated based on the standard calibration curve of each corresponding standard compound. Conversely, individual PAHs were quantified based on the retention time and $m / z$ ratio of authentic PAHs mixed standards (Sigma), and the concentrations of each PAHs were calibrated based on the standard calibration curve. The mixed standard solution of 16 PAHs was purchased from Sigma Aldrich (St. Louis, MO, USA). All solvents in this study (i.e., dichloromethane, $n$-hexane) were chromatography grade and obtained from Dikma (USA). Seven surrogate standards (naphthalene-d8, acenaphthylene-d8, phenanthrene$\mathrm{d} 10$, fluoranthene-d10, pyrene-d10, benzo(a)pyrene-d12 and benzo ( $g, h, i) p e r y l e n e d 12)$ were added to all samples to monitor matrix effects. Quantification was performed using the external standard method. The average recoveries of surrogate standards varied from $81.6 \%$ to $92 \%$. In addition, the detection limit ranged from 0.15 to $0.7 \mathrm{ng} / \mathrm{g}$ dry weight (dw). A Principal Components Analysis (PCA) using varimax rotation was performed using the program SPSS 13.0 for Windows.

\section{Results and discussion}

\subsection{Distribution and sources of n-alkanes}

The Yellow River is the second longest river in China and is frequently referred to as a mud river. Sediments collected in the riverine and estuarine area mainly consisted of fine particles with a grain size $>4 \mu \mathrm{m}$ (silt + sand), while the marine sediments mainly consisted of clay-silt particles with a grain size $<63 \mu \mathrm{m}$ (Fig. 2). The TOC content of surface sediments in the transect of the offshore area was $0.47 \pm 0.10 \%$, which is substantially higher than that of the riverine $(0.09 \pm 0.07 \%)$ and estuarine $(0.06 \pm 0.02 \%)$ sediments. Regression and correlation analyses were employed to investigate the relationship between AH concentration, PAHs concentration, clay content and TOC.

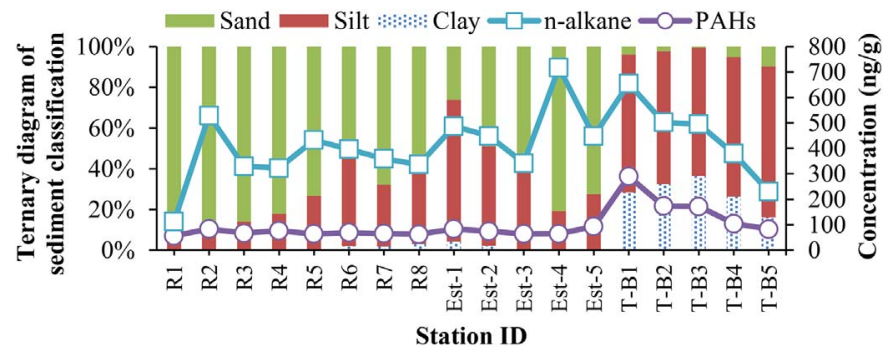

Fig. 2. Distribution of AHs and $\Sigma 16 \mathrm{PAHs}$ concentrations in sediment and ternary diagram showing the sediment classification and deposition patterns.

The correlation coefficient between the PAHs concentrations and clay content $\left(R^{2}=0.56 ; p<0.01\right)$ showed that the organic matter content and grain size composition of the sediment appear to influence the distribution of PAHs in the study area. However, the poor correlation between $\mathrm{AH}$ concentration and clay content $\left(R^{2}=0.01 ; p>0.05\right)$ suggested more complicated effects on the distribution of $n$-alkane.

The levels of AH concentration $\left(\Sigma n-\mathrm{C}_{12-34}\right)$ in estuarine samples was $412.66 \pm 1141.83 \mathrm{ng} / \mathrm{g} \mathrm{dw}$ ), which was substantially higher than that of the riverine sediments $(284.57 \pm 113.02 \mathrm{ng} / \mathrm{g})$ and the offshore area transect $(288 / 14 \pm 84.74 \mathrm{ng} / \mathrm{g})$, and may be due to the accumulation of organic matter as a result of stronger sedimentation in the coastal zone of the Bohai Sea. With the deposition of suspended particles, the pollutants from the river into the sea accumulate in the vicinity of the river estuary. In addition, the total $n$-alkane concentrations in the transect decrease seaward (Fig. 2), which is consistent with the seaward decrease in autogenous organic carbon.

Many different sources may be responsible for $n$-alkane in sediments. Double modal distributions were observed based on the chromatogram characteristics of saturated hydrocarbons in samples from the YRE and adjacent coastal area (Fig. 3). The dominant peaks occur at $n$ - $\mathrm{C}_{13}$ or $n-\mathrm{C}_{14}$ and $n-\mathrm{C}_{29}$ or $n-\mathrm{C}_{31}$ for the short chain $\left(\mathrm{C}_{11}-\mathrm{C}_{20}\right)$ and long chain $\left(\mathrm{C}_{21}-\mathrm{C}_{35}\right) n$-alkanes, respectively. The low molecular weight to high molecular weight ratio (LMW/HMW), and the carbon preference index (CPI), have frequently been used for determining the sources of $n$ alkanes (Prahl et al., 1994; Doskey, 2001; Hui et al., 2009). It has been reported that $\mathrm{LMH} / \mathrm{HMW}$ ratios $>2$ often indicate the presence of fresh oil in sediments, while LMH/HMW ratios $<1$ usually represent terrestrial $n$-alkanes produced by higher plants, marine animals and sedimentary bacteria (Commendatore et al., 2000; Wang et al., 2006). Furthermore, LMW/HMW ratios close to 1 suggests $n$-alkane mainly from petroleum and plankton (Wang et al., 2006). The LMW/HMW ratios of the samples $(1.52 \pm 0.34)$ are all $>1$ but $<2$ for most samples (Fig. 4a). This suggests that the $n$-alkanes originate mainly from petroleum and planktonic sources. Additionally, the lower ratio in riverine and estuarial samples $(1.44 \pm 0.30)$ than marine samples $(1.76 \pm 0.34)$ may be the result of increasing input of anthropogenic hydrocarbons. CPI values close to 1 are regarded as indicating petrogenic input and values $>4$ are associated with natural input inputs (Didky et al., 2000). CPI values in surface sediments from the lower estuary and main estuary $(0.31-0.89)$ are apparently lower than that from the marine region (1.19-2.46). The CPI in the Yellow River contained no obvious odd-even carbon number preferences with CPI values $(0.53 \pm 0.17)$, suggested an increasing input of anthropogenic 

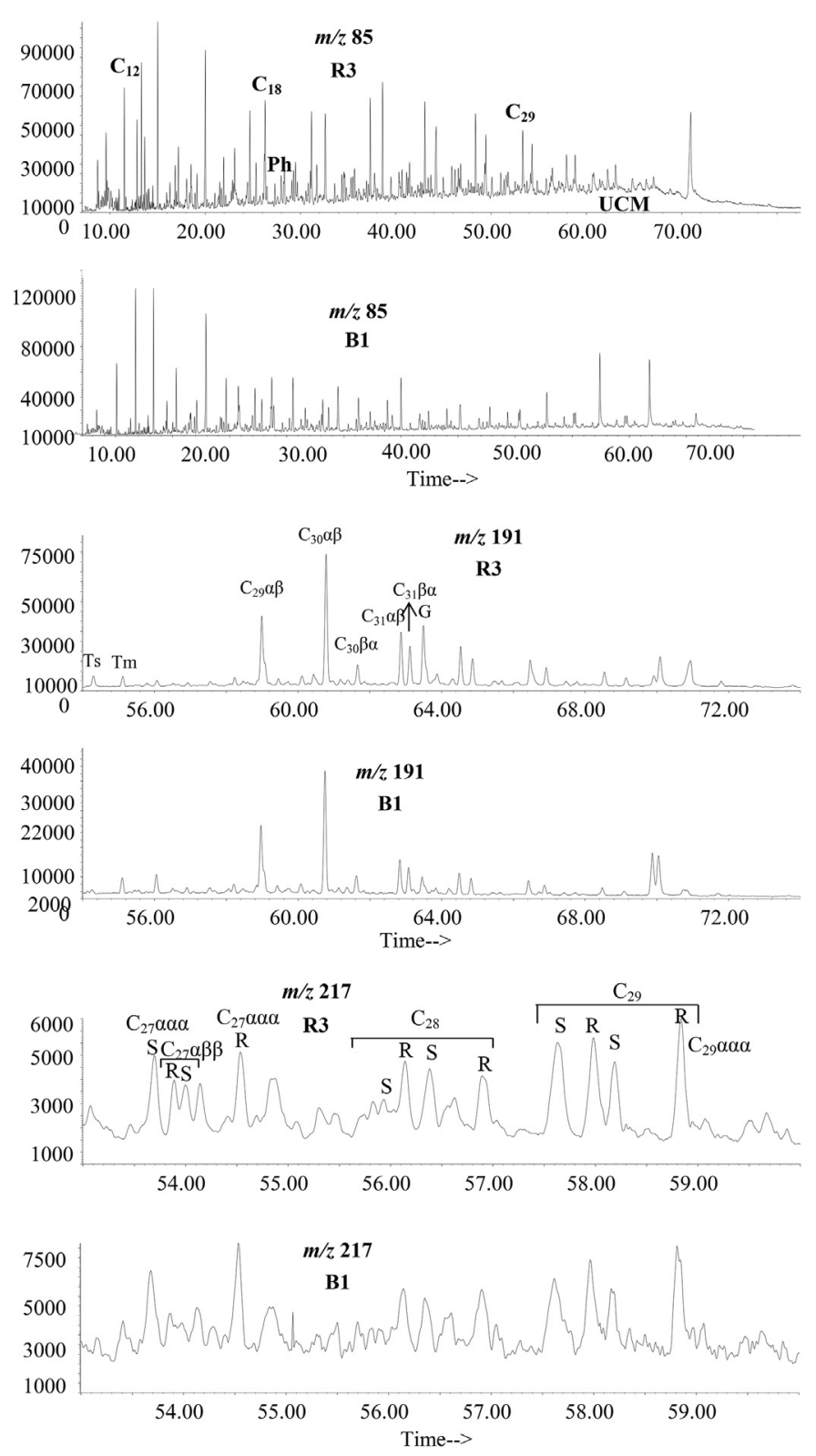

Fig. 3. Mass fragmentogram of $m / z=85$ (alkane), $m / z=191$ (hopanes) and $m / z 217$ (steranes) from sediment in station R3 and B1.

(For hopane, $\alpha, \beta=17 \alpha(\mathrm{H}), 21 \beta(\mathrm{H})$-hopanes; $\beta, \alpha=17 \beta(\mathrm{H}), 21 \alpha(\mathrm{H})$-hopanes; $\mathrm{R}$ and $\mathrm{S}=\mathrm{C}-22 \mathrm{R}$ and S configuration; $\mathrm{G}=$ Gammacerane; Ts $=18 \alpha(\mathrm{H})-22,29,30$-trisnorhopane; $\operatorname{Tm}=17 \alpha(\mathrm{H})-22,29,30$-trisnorhopane. For steranes, $\alpha \alpha \alpha=5 \alpha(\mathrm{H}), 14 \alpha(\mathrm{H})$, $17 \alpha(\mathrm{H})$-steranes; $\alpha \beta \beta=5 \alpha(\mathrm{H}), 14 \beta(\mathrm{H}), 17 \beta(\mathrm{H})$-steranes; R and S $=\mathrm{C}-20 \mathrm{R}$ and S configuration).

hydrocarbons as well as a mixture of marine bacterial inputs (Pearson and Eglinton, 2000; Harji et al., 2008). There was a strong odd-even carbon preference in the high molecular weight $n$-alkanes in the marine samples (Fig. 4b), suggesting terrestrial inputs by the Yellow River. Moreover, the seaward decrease in CPI along the transect B (Fig. 4b) indicates a decrease in the influence of terrigenous material towards the mouth of the estuary.

\subsection{Petroleum biomarkers in sediment}

The low UCM $/ \Sigma n$-alkane $(<10)$ ratio values of this study indicate the presence of pollutants that have been diluted by natural input (Silva et al., 2012). The UCM/ $\Sigma n$-alkane ratio values ranged from 1.66 to 1.68 , showing the biodegradation of petroleum related input to be an important factor. Other indicators of petroleum contamination are

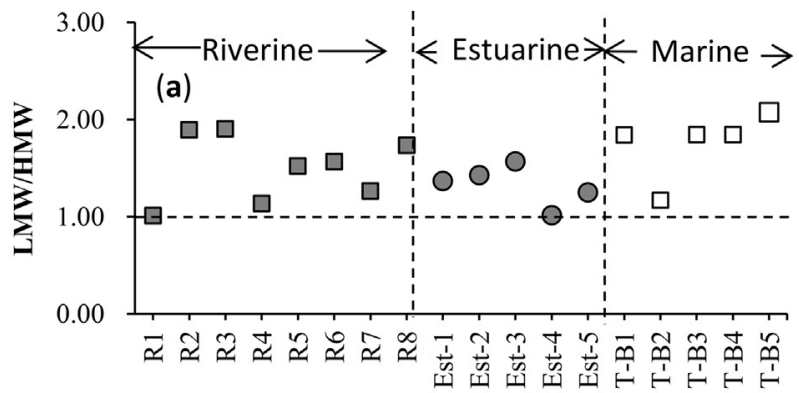

Station ID

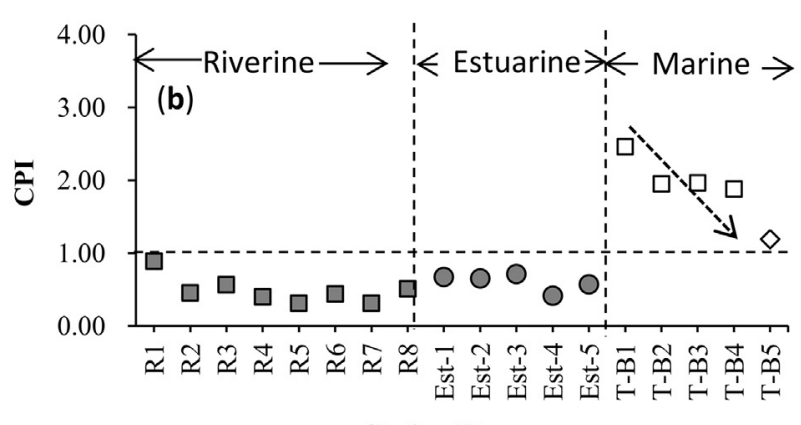

Station ID

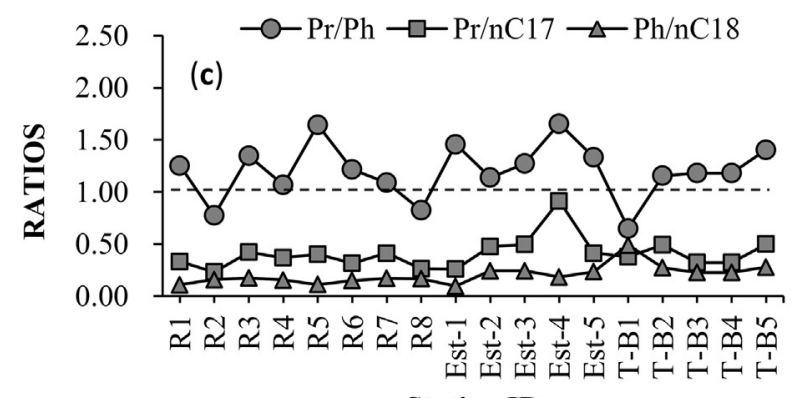

Station ID

Fig. 4. Spatial variations of LMW/HMW ratios (a), CPI (b), $\mathrm{Pr} / \mathrm{Ph}, \mathrm{Pr} / n-\mathrm{C}_{17}$ and $\mathrm{Ph} / n-\mathrm{C}_{18}$ ratios (c) in surface sediments.

Note: LMW/HMW: [Sum of Low Molecular Weight $\left(n \mathrm{C}_{12}\right.$ to $\left.\left.n \mathrm{C}_{21}\right)\right] /[$ Sum of High Molecular Weight $\left(n \mathrm{C}_{22}\right.$ to $\left.\left.n \mathrm{C}_{34}\right)\right] n$-alkanes ratio; CPI: Carbon Preference Index calculated as $2\left(\mathrm{C}_{25}+\mathrm{C}_{27}+\mathrm{C}_{29}\right) /\left(\mathrm{C}_{24}+2\left(\mathrm{C}_{26}+\mathrm{C}_{28}+\mathrm{C}_{30}\right)+\mathrm{C}_{32}\right)$.

isoprenoids, such as pristane (Pr) and phytane (Ph) (Volkman et al., 1992). It has been reported that the $\mathrm{Pr} / \mathrm{Ph}$ ratio in uncontaminated sediments is typically between 3 and 5 (Steinhauer and Boehm, 1992). Furthermore, $\mathrm{Pr} / \mathrm{Ph}$ values less or close to 1 is regarded as petroleum pollution (Steinhauer and Boehm, 1992). However, the Pr/Ph ratio was low (1.20 \pm 0.27) in our studied samples (Fig. 4c), indicating a predominantly petroleum source rather than a biogenic source. For the studied stations, low ratio values of $<1$ for $\mathrm{Pr} / n-\mathrm{C}_{17}(0.41 \pm 0.15)$ and $\mathrm{Ph} / n-\mathrm{C}_{18}(0.21 \pm 0.09)$ were found (Fig. $4 \mathrm{c}$ ), which confirms recent oil pollution inputs (Mille et al., 2007; Commendatore et al., 2012).

Additional supporting evidence for the presence of oil pollution is the identification of hopane and sterane series detected in the GC-MS analysis $(m / z 191,217)$. The distribution of hopanes is characterized by the predominance of $\mathrm{C}_{30} 17 \alpha(\mathrm{H})$ and $21 \beta(\mathrm{H})$-hopane, but by less prominent $21 \beta(\mathrm{H}), 17 \alpha(\mathrm{H})$-hopane, and with a smooth decrease in the abundance of $\mathrm{C}_{31-35}$ homohopanes in these series. Gammacerane, a biomarker commonly found in most Chinese crude oil geologically derived from lacustrine sources (Philp and Fan, 1987), was also present in all studied samples. Similar hopane distributions were also reported for the crude oils from the Shengli Oilfield (Pang et al., 2003). The abundances of $\mathrm{C}_{27}, \mathrm{C}_{28}$ and $\mathrm{C}_{29}$ steranes were high in the samples. The 
pattern of 3 regular sterane series in an order of $\mathrm{C}_{29}>\mathrm{C}_{27}>\mathrm{C}_{28}$ suggested that the sedimentary petroleum contamination was mainly derived from mixed terrigenous and algal-bacterial organic matter dominated by higher plants. Maturity indicators based on terpanes and steranes, such as the $\mathrm{C}_{31} 22 \mathrm{~S} /(22 \mathrm{~S}+22 \mathrm{R})$ and $\mathrm{C}_{29} 20 \mathrm{~S} /(20 \mathrm{~S}+20 \mathrm{R})$ ratio (0.5 at equilibrium; Peters et al., 2005), also show only minor variations $(0.57 \pm 0.02$ and $0.43 \pm 0.02$, respectively) among the analyzed samples and have a high maturity level. The hopane and starane patterns in the study area further confirm the presence of pollutant inputs from petroleum, as already suggested by the presence of UCM, pristane and phytane.

\subsection{PAHs in sediment-water systems}

\subsubsection{Levels and spatial distribution of PAHs in sediments}

The distributions of PAHs in the sediments are influenced by the clay and organic matter content of the sediment. PAHs are mainly adsorbed in the clay particles, which have a greater capacity for adsorption due to their greater specific surface area (Mayer, 1994). The sediments with higher organic matter content have a strong affinity to hydrophobic compounds such as PAHs, in comparison with sediments with low levels of organic matter. In general, the concentrations of PAHs in surface sediments are mainly controlled by the following processes: (i) rate of $\mathrm{PAH}$ input, (ii) rate of sediment input, (iii) microbial degradation of PAHs and (iv) vertical mixing, resuspension and redeposition of PAHs and sediment due to biological or physical processes (Boonyatumanond et al., 2006). 16 US EPA priority PAHs (16 PAHs) in sediment samples were measured at a detectable level in this study. The total PAHs concentrations ( $\Sigma 16 \mathrm{PAHs}$ ) ranged from $56.69 \mathrm{ng} / \mathrm{g}$ to $227.96 \mathrm{ng} / \mathrm{g}$, with a mean of $111.14 \pm 59.70 \mathrm{ng} / \mathrm{g}$ dry weights (dw). The $\Sigma 16 \mathrm{PAHs}$ in the offshore area transect was $151.08 \pm 62.14 \%$, which is noticeably higher than that of the riverine sediments $(69.84 \pm 9.37 \%)$ and estuarine samples $(74.28 \pm 13.42 \%)$. This may be due to the higher clay content in the marine area or the accumulation of organic matter due to stronger sedimentation in the coastal zone of the Bohai Sea. Furthermore, the oilgas drilling platforms located in the north of the YRE may also contribute to the petroleum-derived PAHs in this area. Other processes, such as vertical mixing due to biological or physical processes, may also effect the PAHs distribution (Boonyatumanond et al., 2006). Higher activity in riverine areas may also contribute to the higher PAHs concentrations. In addition, the $\Sigma 16 \mathrm{PAHs}$ showed an overall pattern of a seaward decrease (Fig. 5a, b), especially the section B near the estuary, suggesting a decrease in land-sourced pollutants in the offshore direction.

\subsubsection{Spatial-temporal variations of PAHs in water}

For water samples collected in the flooding season, the PAHs levels exhibited the following order from high to low: river inflows $>$ marine area $>$ estuary (Fig. 5c). Similar trends were found in the dry season. This suggests that the industrial and anthropogenic emissions in the Yellow River are the most important PAHs sources of the YRE area. The migration and settlement of pollutant and terrigenous input material in the offshore region in the offshore region, lead to the accumulation of pollutants. Such cumulative effect may contribute to higher PAHs levels in the marine area.

Obvious seasonal trends in PAH16 exist in the water. The results illustrated that lower PAHs concentrations $(537.42 \pm 200.11 \mathrm{ng} / \mathrm{L})$ were observed in the water during the flooding season, while higher PAHs concentrations $(1539.12 \pm 161.51 \mathrm{ng} / \mathrm{L})$ occurred in the water during the dry season. SPM is the most active absorbent of PAHs in water bodies. PAHs in water are mainly in the dissolved phase form during the dry season, while during the flooding season they are predominantly in the dissolved phase and particulate phase forms (Fig. 6). The seasonal variation in PAHs concentrations was attributed to the variation in water flow of the Yellow River, which could cause a change
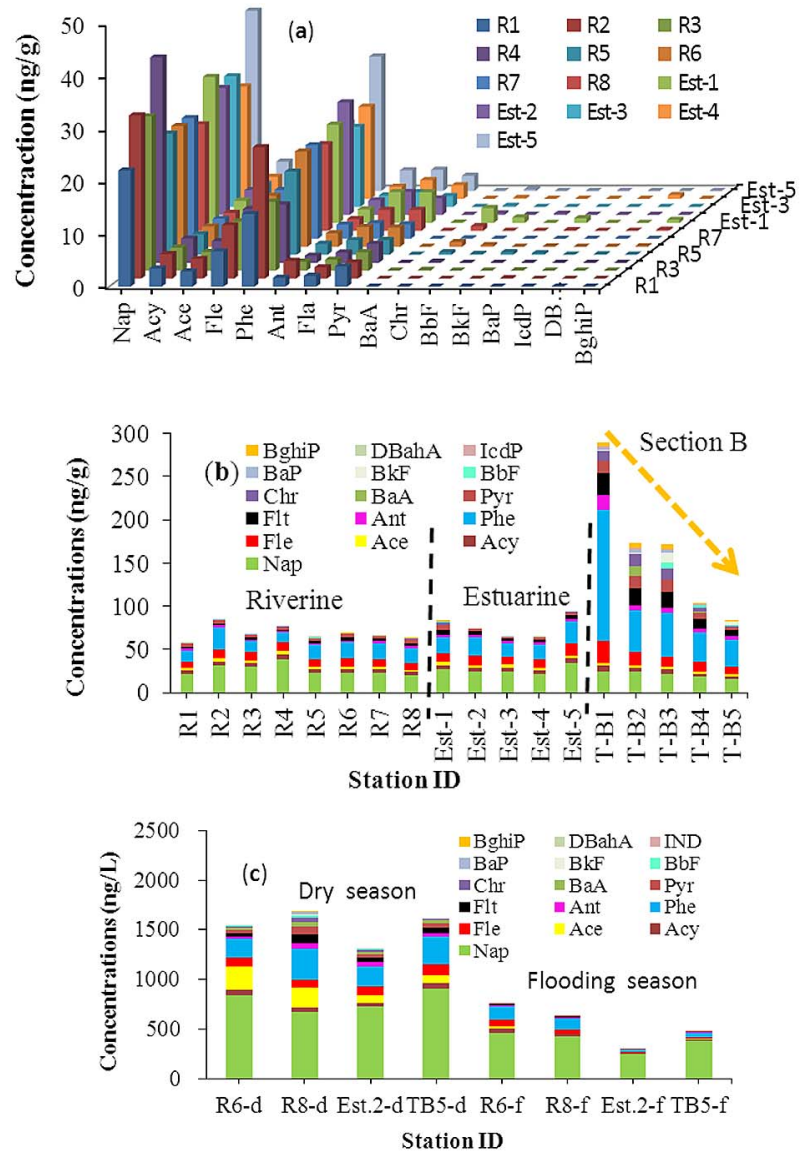

Fig. 5. Concentrations and composition of 16 PAHs in surface sediments (a) (b) and water (c).

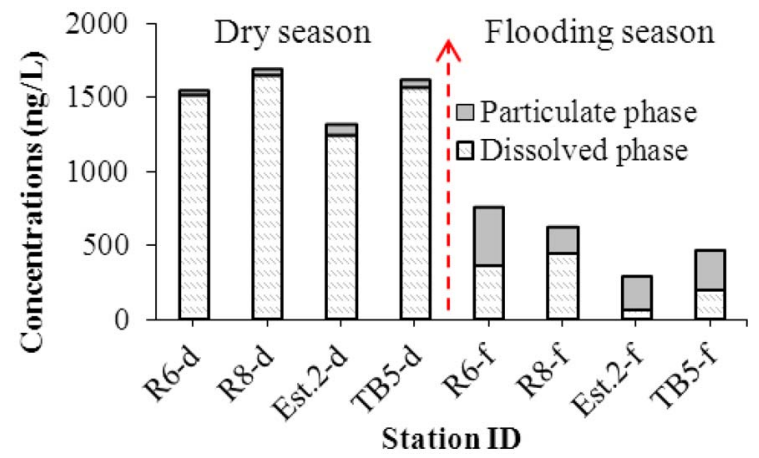

Fig. 6. Spatial and temporal distribution of PAHs in water.

in the dilution ratio. Generally, a high flow rate of river water results in a good dilution ratio in the flooding season and leads to reduced PAHs concentrations in the Yellow River. The PAHs concentration in the dry season is higher than that of the flooding season, which may be due to water dynamics. As is well-known, the stronger hydrodynamic force in the flooding season may easily carry larger particles with weak adsorption. However, more abundant small particulate matter in the water during the dry season may contribute to the adsorbance of particulate organic carbon (POC) and PAHs. A similar distribution was also reported by Ou et al. (2009) for the PAHs distribution in overlying waters from the Yangtze estuarine and coastal areas. The PAHs concentration in overlying waters in the dry season (1988 ng/L) was higher than that in flood season $(1727 \mathrm{ng} / \mathrm{L})$.

\subsubsection{Distribution patterns of PAHs}

PAHs in the water and sediment were all dominated by LMW-PAHs 


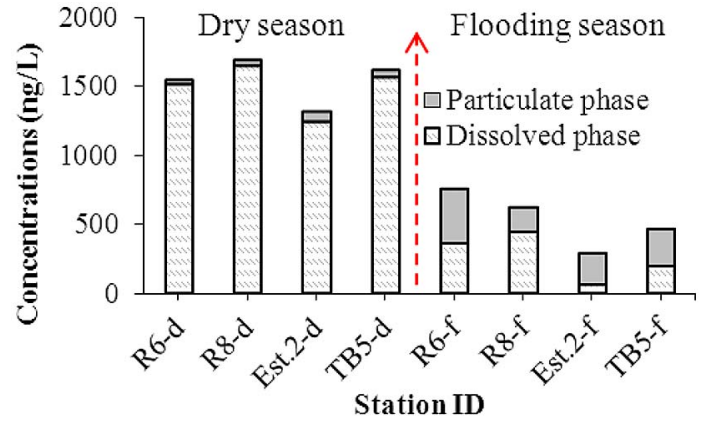

Fig. 7. Comparative PAHs composition in water and sediments according to the number of rings in the chemical structure.

(2- to 3-ring PAHs), accounting for $>60 \%$ of the total PAHs at each station (Fig. 7). Apart from TB-1 station near the YRE, the relative abundance of high-ring (4-, 5-, 6-ring) PAHs was enriched in the marine area, and its content displayed a general seaward decrease. According to Tolosa and Bayona (1996), the petroleum-derived residues contain a relatively higher concentration of 2- and 3-ring PAHs. For example, a higher concentration of phenanthrene has been observed in surface sediments as a result of contamination by fresh oil (Yunker et al., 2002; Zakaria et al., 2002). Higher water solubility of low molecular weight PAHs compared to the heavy PAHs may explain their comparatively high abundance detected in water (Sarria-Villa et al., 2016). In addition, the high content of low-ring (2- and 3-ring) PAHs suggests a local source of PAHs or otherwise a relatively recent introduction of PAHs (Hu et al., 2010), as low-ring PAHs are prone to desorption and degradation in sediments during the transportation process (Pichler et al., 1996; Shi et al., 2005). The YRD has experienced rapid development over the past 40 years due to the exploitation of the Shengli Oilfield, the second largest oil field in China. For example, Sites R5-R8 are close to 2 oilfields (Gudao and Gudong). Furthermore, the Bohai Sea is scattered with a number of oil drilling platforms, and the Chengdao offshore oilfield, part of the land-based Shengli Oilfield, is located in the north of the YRE marine area. Thus, the detection of petroleum-based contaminants in this area is not surprising.

\subsubsection{Sources identification of PAHs}

3.3.4.1. Sources identified by PAHs diagnostic ratios. In general, LMWPAHs originate from petroleum products, incomplete combustion of fossil fuels and biomass at low to moderate temperatures and natural digenesis, while HMW-PAHs are mainly formed via the incomplete combustion processes of organic materials at high temperatures (Mai et al., 2002; Rahmanpoor et al., 2014). The ratio of LMW to HMW is used to differentiate petrogenic and pyrogenic PAHs. The range of LMW/HMW of riverine samples, estuarine samples and marine samples were $7.8-12.86,7.8-10.75$ and $1.18-4.70$, respectively. The LMW/ HMW ratios varied from 1.18 to 14.62 with a mean of $5.56 \pm 3.89$, which suggested that petroleum was the major contributor of PAHs contamination in this area.

The source of PAHs detected in the sediment can further be determined by the molecular ratios of some PAHs. The mass 178 (anthracene + phenanthrene), 202 (fluoranthene + pyrene) and 276 isomers (indeno( $1,2,3 \mathrm{~cd}$ ) pyrene + benzo(ghi)Perylene) have the greatest range in stability and hence are good indicators of thermodynamics vs. kinetic (e.g. petroleum vs. combustion) (Yunker et al., 2002). Thus, $\mathrm{PAH}$ isomer ratios, such as fluoranthene/(fluoranthene + pyrene) (Flt/ [Flt + Pyr]), anthracene/(anthracene + phenanthrene) (Ant/[Ant + Phy]), and indeno[1,2,3-cd]pyrene/(indeno[1,2,3-cd]pyrene + benzo[ghi]perylene) (IcdP/[IcdP + BghiP]) have been widely used to infer the possible sources of PAHs (Budzinski et al., 1997; Yunker et al., 2002; Zhang et al., 2004; Yang et al., 2009). PAHs of molecular mass 178 and 202 are commonly used to distinguish between combustion and petroleum sources. Based on the PAHs isomer pair ratio
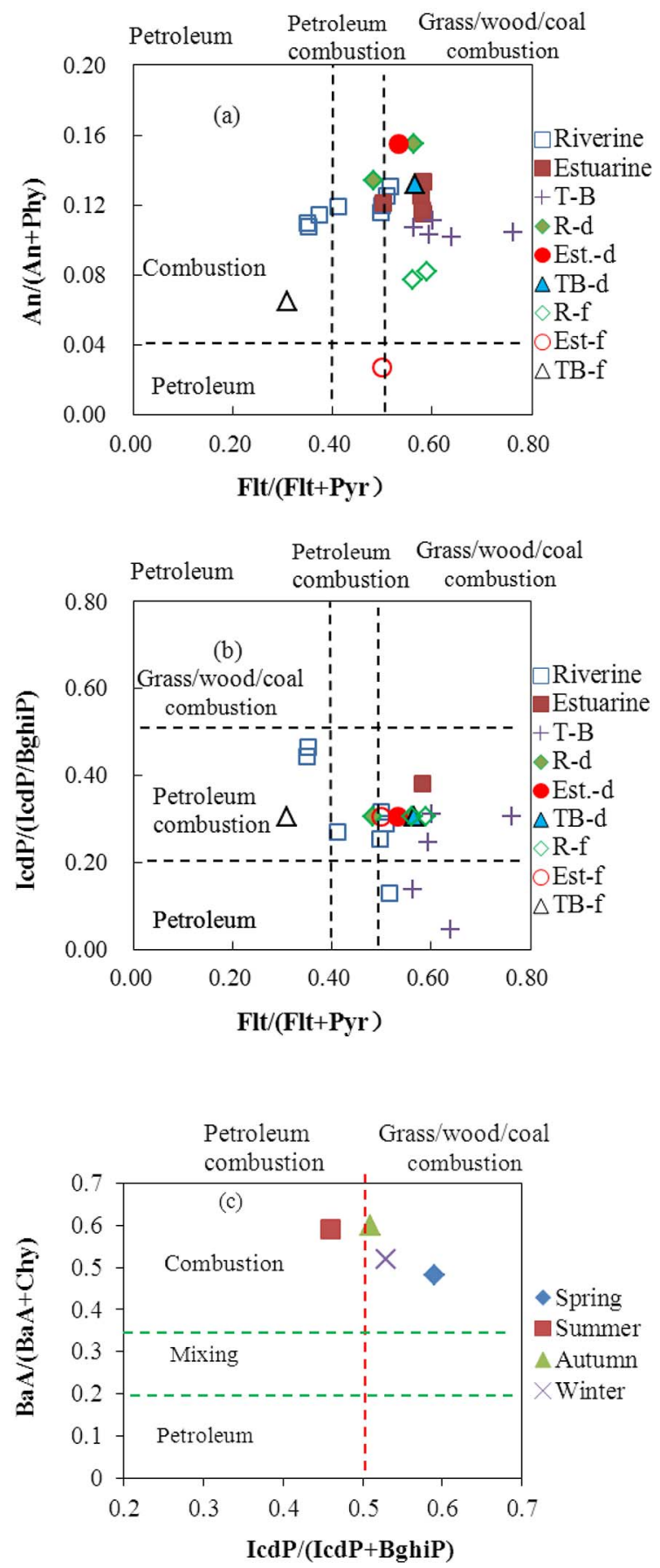

Fig. 8. Plots of PAH isomer pair ratios for source identification: (a) Ant/(Ant + Phy) versus Flt/(Flt + Pyr) of sediment and water, (b) IcdP/(IcdP + BghiP) versus Flt/(Flt + Pyr) of sediment and water, (c) IcdP/(IcdP + BghiP) versus $\mathrm{BaA} /(\mathrm{BaA}+\mathrm{Chr})$ of particulate PAHs from air.

Note: -d: samples collected from dry season; -f: samples collected from flooding season.

measurements compiled by Yunker et al. (2002): Flt/(Flt + Pyr) $<0.4$ implies a petroleum origin; between 0.4 and 0.5 implies petroleum combustion; and $>0.5$ as combustion of coal and biomass. IcdP/(IcdP + BghiP) of $<0.20$ indicates a petroleum source; $>0.50$ indicates combustion contribution of biomass and coal sources and between 0.20 and 0.50 indicates liquid fossil fuel combustion. An Ant/(Ant + Phe) ratio $<0.10$ is seen in petroleum input or diagenetic sources, whereas values $>0.1$ are characteristic of combustion processes.

Cross plots of such ratios and their cut-off values for the various predicted PAHs sources are shown in Fig. 8a, b. It is evident that the 
riverine samples exhibited greater evidence of petroleum pollution, while the primary sources of sedimentary PAHs for other samples from estuarine and marine areas include biomass and coal combustion. Moreover, the PAHs in surface sediments from the Bohai Sea were mostly of pyrogenic origin. With the exception of pyrolytic inputs, petrogenic units may also be a main source for PAHs as the oil platform of Shengli Oilfield could potentially contribute some PAHs. It can be observed from Fig. 8a, b that the PAHs in the water comprise mixed pyrolytic and petrogenic sources at some sites, which is probably due to the petroleum industries and oilfields located in this studied area. In addition, the studied samples had values of the $\mathrm{BaA} /(\mathrm{BaA}+\mathrm{Chr})$ over than 0.35 which implied biomass and coal combustion; which further confirmed by IcdP/(IcdP + BghiP) ratio value higher than 0.50 except summer sample (petroleum combustion) (Fig. 8c). The coal combustion and traffic emissions were the main particulate PAHs sources across the 4 seasons. On the whole, pyrogenic sources are the major origins of PAHs in water from the Yellow River, the Bohai sediments as well as particulate PAHs from the air. Energy consumption is a predominant reason for PAHs pollution in northern China. In northern China, the main energy source is coal. In some rural areas of northern China still use wood as main energy source. The contamination of sediments with petrogenic PAHs contrasts with the results from industrialized countries where pyrogenic PAHs are dominant in urban aquatic environments (Budzinski et al., 1997; Boonyatumanond et al., 2006; Rodrigo et al., 2016). For example, the upstream riverine runoff from the Pearl River Delta (Zhang et al., 2012) and the Colombian Cauca River (Rodrigo et al., 2016) is contaminated mainly with pyrogenic PAHs.

3.3.4.2. A natural diagenetic origin: perylene versus anthropogenic $P A H s$. Perylene, as a 5-ring $\mathrm{PAH}$, has been widely found in varied sediment environments, and is usually thought to be a diagenetic product from its natural biogenic precursors via post-depositional formation under anoxic conditions (Silliman et al., 2001). As compared to 16PAHs, the perylene levels showed a significant decrease from the lower stretch of the estuary $(0.14-2.46 \mathrm{ng} / \mathrm{g})$ to the main estuary $(0.24-0.85 \mathrm{ng} / \mathrm{g})$ and the offshore area of the Bohai Sea (0.03-0.17 ng/g). Furthermore, the ratios of perylene concentrations relative to the penta-aromatic hydrocarbons (perylene/5-ring PAHs) were all above $0.12-0.46$ in this study (Fig. 9), indicating a predominantly diagenetic origin for perylene with its precursors originating from terrigenous inputs by river runoff (Baumard et al., 1998; Hu et al., 2011). The relatively higher proportion of perylene towards the PAHs in the recent coastal sediments off China has also been observed, such as the Bohai Sea (1.5-9.6 ng/g, Hu et al., 2011), East China Sea (7.4-141.1 ng/g, Hu et al., 2014), the Pearl River Estuary and the adjacent South China Sea (101-586 ng/g, Mai et al., 2002), which are likely to be a potential terrigenous input indicators on these continental margins.

\subsection{Ranking AHs and PAHs concentration in rivers of the world}

In this study, only $\mathrm{AH}$ analysis in sediments was performed. The

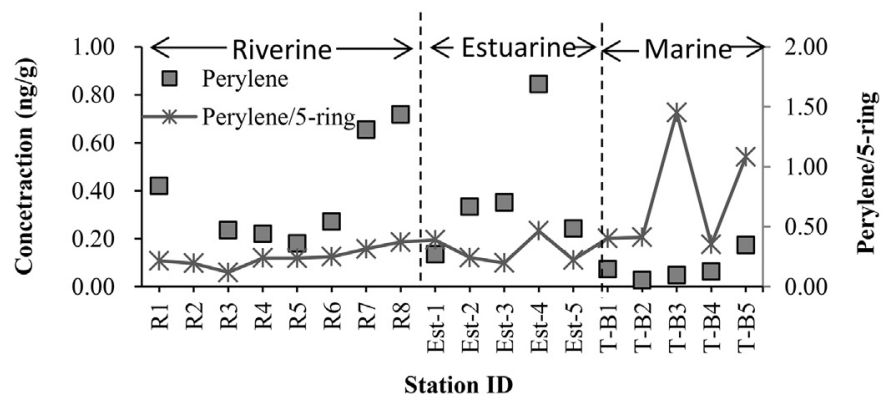

Fig. 9. Abundance of sedimentary perylene and the ratio of perylene to 5-rings PAHs in surface sediments. levels of $\mathrm{AH}$ concentration $\left(\Sigma n-\mathrm{C}_{12-34}\right)$ of the studied sediments was $321.14 \pm 122.86 \mathrm{ng} / \mathrm{g}$ dry weight, which is relatively lower or moderate compared to those of global locations reported to be chronically contaminated by oil, such as $160-1880 \mathrm{ng} / \mathrm{g}$ in the Yangtze River Estuary (Bouloubassi et al., 2001), 500-8120 ng/g in Jiaozhou Bay (Wang et al., 2006), 1440-70,410 ng/g in highly contaminated sediments from Liaohe Delta (Lin et al., 2013), 800-2600 ng/g in coastal Caspian Sea, Iran (Tolosa et al., 2004) and 1388-5896 ng/g in the Andaman Backarc Basin, Indian Ocean (Venkatesan et al., 2003).

Compared with the other areas in the world (Table 2), PAHs contamination levels in this study (56.69-227.96 ng/g dw) were close to those detected in the sediments of the Yangtze River Estuary (90.14-502.12 ng/g dw) and Santander Bay, Spain (0.35-344.60 ng/g $\mathrm{dw}$ ), but was lower than those reported from Pearl River Delta (134-2432 ng/g dw), Haihe River, China (134-2432 ng/g dw) and along the Mediterranean coast in Egypt (3.5-14,100 ng/g dw). However, PAHs contamination was higher in our samples from the YRE and the adjacent coastal area than that reported in the Chongming wetlands near Shanghai, China (38.7-136.2 ng/g dw), Kishon River, Israel (34.2-188 ng/g dw), suggesting low or moderate contamination levels in the studied area. In conclusion, the concentration of PAHs in sediments from the YRE and adjacent coastal area is relatively low compared to other estuaries around the world (Table 2).

Table 2 displays a comparison between the levels of PAHs measured in this study versus those reported in other rivers worldwide. Compared to the YRE and adjacent coastal area $(0.449-1.644 \mu \mathrm{g} / \mathrm{L})$, higher concentrations were detected in the water from the Liaohe River, China (0.946-13.449) and Gomti River, India (0.06-75.57 $\mu \mathrm{g} / \mathrm{L})$. In turn, lower concentrations were detected in the water from the Mississippi River, US (0.006-0.069 $\mu \mathrm{g} / \mathrm{L})$, Seine River, France $(0.004-0.036 \mu \mathrm{g} / \mathrm{L})$ and Luanhe rivers, China $(0.097-0.309 \mu \mathrm{g} / \mathrm{L})$. SPM, as the most active absorbent of PAHs in water bodies, plays a vital role in PAHs transportation in aquatic multimedia. The $\Sigma \mathrm{PAH}$ concentration in the Liaohe River (0.318-238.52 $\mu \mathrm{g} / \mathrm{L})$, Pearl River Delta $(0.442-16.489 \mu \mathrm{g} / \mathrm{L})$, Mississippi River (1.3-7.0 $\mu \mathrm{g} / \mathrm{L})$ and Seine River (1.0-14.0 $\mu \mathrm{g} / \mathrm{L})$ were higher than the YRE and adjacent coastal area $(0.029-0.39 \mu \mathrm{g} / \mathrm{L})$. The well-developed economy and associated large sewage discharge around these areas may be the primary explanation.

\subsection{Ecological risk assessment of PAHs in sediments}

PAHs have gained increasing attention for their high stability, low solubility and toxic, carcinogenic and mutagenic effects. According to Baumard et al. (1998), sediments can be characterized as low, moderate, high, and very highly polluted with PAHs when the total PAH concentrations are $0-100 \mathrm{ng} / \mathrm{g}, 100-1000 \mathrm{ng} / \mathrm{g}, 1000-5000 \mathrm{ng} / \mathrm{g}$ and $>5000 \mathrm{ng} / \mathrm{g}$, respectively. Based on this classification, PAHs of sediments from the YRD estuary (56.69-290.04 ng/g dw) can be considered as low to moderate.

The Sediment Quality Guidelines (SQGs) have also been well applied in sediment quality and ecological risk assessments (Long et al., 1995, 2006; Qiao et al., 2006; Quiroz et al., 2010). Specifically, the previously published SQGs for the protection of sediment-dwelling organisms were grouped into different categories: threshold effect levels (TELs), effect range low values (ERLs), probable effect levels (PELs) and effect range median values (ERMs; Long et al., 1998, 2006). Two sets of SQGs, including (a) the ERL/ERM and (b) the TEL/PEL values, were applied in this study to assess the ecological toxicity of individual PAHs concentrations in sediments (Table 3 ). In the 3 ranges of chemical concentrations, adverse biological effects were expected rarely ( $<$ ERL/TEL), occasionally ( $\geq$ ERL/TEL and $<$ ERM/PEL) and frequently ( $\geq$ ERM/PEL; Long et al., 1995; Liu et al., 2009). The measured concentrations of PAHs were compared with the SQGs. This indicated that PAH concentrations were below the ERL and PEL values at all stations. Naphthalene, acenaphthene, fluorine and phenanthrene concentrations were in the intermediate range ( $\geq \mathrm{ERL} / \mathrm{TEL}$ and $<\mathrm{ERM}$ / 
Table 2

$\Sigma$ PAHs concentrations in sediments from different locations.

\begin{tabular}{|c|c|c|c|c|}
\hline \multirow[t]{2}{*}{ Phases } & \multirow[t]{2}{*}{ Sampling sites } & \multicolumn{2}{|c|}{$\Sigma$ PAHs (ng/g or $\mu \mathrm{g} / \mathrm{L}$ ) } & \multirow[t]{2}{*}{ Reference } \\
\hline & & Range & Mean & \\
\hline \multirow[t]{6}{*}{ Water } & Yellow River Delta & $0.449-1.644$ & 0.882 & This study \\
\hline & Liaohe River, China & $0.946-13.449$ & 6.445 & Guo et al. (2007) \\
\hline & Luanhe, China & $0.097-0.309$ & ND & Li et al. (2010) \\
\hline & Mississippi River, US & $0.006-0.069$ & 0.041 & Mitra and Bianchi (2003) \\
\hline & Gomti River, India & $0.06-75.57$ & 9.440 & Malik et al. (2011) \\
\hline & Seine River, France & $0.004-0.036$ & 0.02 & Fernandes et al. (1997) \\
\hline \multirow[t]{5}{*}{ SPM } & Yellow River Delta & $0.029-0.39$ & 0.726 & This study \\
\hline & Pearl River Delta, China & $0.442-16.489$ & 0.160 & Luo et al. (2006) \\
\hline & Liaohe River basin, China & $0.318-238.52$ & 21.725 & Guo et al. (2007) \\
\hline & Mississippi River, US & $1.3-7.0$ & ND & Mitra and Bianchi (2003) \\
\hline & Seine River, France & $1-14$ & 5 & Fernandes et al. (1997) \\
\hline \multirow[t]{8}{*}{ Sediment } & Yellow River Delta & $56.69-227.96$ & 111.14 & This study \\
\hline & Yangtze River Estuary, China & $90.14-502.12$ & 259.1 & Hui et al. (2009) \\
\hline & Haihe River, China & $134-2432$ & $27,074.08$ & Bin et al. (2007) \\
\hline & Pearl River Delta, China & $134-2432$ & 885.17 & Mai et al. (2002) \\
\hline & Chongming wetlands, China & $38.7-136.2$ & 107.05 & Wang et al. (2012) \\
\hline & Santander Bay, Spain & $0.35-344.60$ & 59.59 & Viguri et al. (2002) \\
\hline & Mediterranean coast, Egypt & $3.5-14,100$ & 787.24 & Barakat et al. (2011) \\
\hline & Kishon River, Israel & $34.2-188$ & 100.68 & Oren et al. (2006) \\
\hline
\end{tabular}

Note: concentration of water: $\mu \mathrm{g} / \mathrm{L}$; concentration of sediment and SPM: $\mu \mathrm{g} / \mathrm{g}$; ND: not detected.

Table 3

Toxicity guidelines of PAHs compounds for surface sediments from YRE and adjacent coastal area.

\begin{tabular}{lllllllll}
\hline \multirow{2}{*}{ PAHs } & \multicolumn{2}{l}{ Guideline } & & & \multicolumn{2}{l}{ Yellow River Estuary } \\
\cline { 2 - 5 } \cline { 7 - 9 } & ERL & ERM & TEL & PEL & & Riverine & Estuarine & Marine \\
\hline Nap & 160 & 2100 & 34.6 & 391 & & $20.28-39.07$ & $21.39-34.32$ & $15.58-24.96$ \\
Ace & 16 & 500 & 6.71 & 88.9 & & $2.67-4.14$ & $2.71-3.54$ & $2.46-3.11$ \\
Acy & 44 & 640 & 5.87 & 128 & & $3.46-4.61$ & $4.2-5.56$ & $3.38-6.69$ \\
Flu & 19 & 540 & 21.2 & 144 & & $6.71-10.22$ & $9.30-13.04$ & $7.94-24.82$ \\
Phe & 240 & 1500 & 86.7 & 544 & & $11.08-25.02$ & $15.22-25.57$ & $32.26-152.25$ \\
Ant & 85.3 & 1100 & 46.9 & 245 & & $1.70-3.39$ & $2.17-3.94$ & $3.75-17.15$ \\
Fla & 600 & 5100 & 113 & 1494 & & $1.95-3.97$ & $2.79-4.38$ & $7.31-24.79$ \\
Pyr & 665 & 2600 & 153 & 1398 & & $2.82-5.81$ & $2.05-3.13$ & $2.26-24.76$ \\
BaA & 261 & 1600 & 74.8 & 693 & & $0.00-0.02$ & 0.00 & $0.01-10.57$ \\
Chr & 384 & 2800 & 108 & 846 & & $0.00-2.82$ & $0.19-0.27$ & $1.76-14.19$ \\
BaP & 430 & 1600 & 88.8 & 763 & & $0.00-0.87$ & $0.00-0.01$ & $0.17-2.95$ \\
DBahA & 63.4 & 260 & 6.22 & 135 & & $0.00-0.09$ & $0.00-0.73$ & $0.00-0.62$ \\
\hline
\end{tabular}

Note: Nap: naphthalene, Ace: acenaphthene, Acy: acenaphthylene, Flu: fluorene, Phe: phenanthrene, Ant: anthracene, Fla.: fluoranthene, Pyr: pyrene, BaA: benz $[a]$ anthracene, Chr: chrysene, BaP: benzo[a]pyrene, DBahA: dibenz $[a, h]$ anthracene.

PEL) at stations R3 and T-B1, indicating that occasional adverse biological effects are likely to occur for such compounds at the 3 stations. In the other stations, naphthalene, acenaphthene, fluorine and phenanthrene concentrations were below ERLs/TELs. It may be concluded that PAHs will not cause immediate adverse biological effects in the sedimentary environment in the YRE and adjacent coastal area. On the whole, the ecosystem risk of PAHs studied there was relatively low.

\section{Conclusion}

The levels of AHs concentration $\left(\Sigma n-\mathrm{C}_{12-34}\right)$ in estuarine samples were higher than that of the riverine sediments and the offshore area transect. PAHs in surface water levels exhibited the following order from high to low: river inflows $>$ marine area $>$ estuary. The AHs and $\Sigma 16 \mathrm{PAHs}$ showed an overall pattern of a seaward decrease for section $B$, which is consistent with the seaward decrease in autogenous organic carbon. The results illustrated that lower PAHs concentrations (537.42 $\pm 200.11 \mathrm{ng} / \mathrm{L})$ were observed in water during the flooding season, while higher PAH concentrations $(1539.12 \pm 161.51 \mathrm{ng} / \mathrm{L})$ occurred in water during the dry season. Additionally, PAHs in water were primarily in the dissolved phase form during the flooding season, while during the dry season they were mainly in the dissolved and particulate phase forms. The concentrations of PAHs in the sediment and SPM from the YRE and adjacent coastal area are relatively low compared to those in other estuaries around the world. The isomeric ratios of PAHs indicated that coal combustion, petroleum combustion and spilled oil were dominant in the sediments of the YRE and adjacent coastal area. The spatial distribution of the LMW/HMW ratio and CPI in sediments is mainly controlled by the mixing inputs of terrigenous and marine components. The hopane and starane patterns further confirmed the presence of pollutant inputs from petroleum, as already suggested by the presence of UCM, pristane and phytane. Overall toxicity assessments suggested that PAH exposure was at a low potential in terms of the eco-toxicological effects on organisms in the YRE and adjacent coastal area. No simultaneous collection of PAHs in the air was done in this study. It is necessary to better understand the migration and transformation process of PAHs in the air-water-sediment systems samples, so it is necessary to strengthen the research in this field.

\section{Acknowledgements}

We thank LetPub (www.letpub.com) for its linguistic assistance during the preparation of this manuscript. This study was co-supported by International cooperation, CAS, Chinese-foreign cooperation in key projects (133337KYSB20160002), Youth Foundation of Shandong Institute of Business and Technology (2014QN004), Science and technology service network initiative, CAS (KFJ-EW-STS-127), Project of on-site sediment microbial remediation of public area of central Bohai Sea, North China Sea Branch of State Oceanic Administration (QDZC20150420-002).

\section{References}

Barakat, A.O., Mostafa, A., Wade, T.L., Sweet, S.T., El Sayed, N.B., 2011. Distribution and characteristics of PAHs in sediments from the Mediterranean coastal environment of Egypt. Mar. Pollut. Bull. 62, 1969-1978.

Baumard, P., Budzinski, H., Garrigues, P., Sorbe, J.C., Burgeot, T., Bellocq, J., 1998. Concentration of PAHs (polycyclic aromatic hydrocarbons) in various marine organisms in relation to those in sediments and to tropic level. Mar. Pollut. Bull. 30, 951-960.

Bin, J.A., Zheng, H.L., Huang, G.Q., Ding, H., Su, H.T., Li, R., Li, X.G., 2007. Characterization and distribution of polycyclic aromatic hydrocarbon in sediments of Haihe River, Tianjin, China. J. Environ. Sci. 19, 306-311. 
Boonyatumanond, R., Wattayakorn, G., Togo, A., Takada, H., 2006. Distribution and origins of polycyclic aromatic hydrocarbons (PAHs) in riverine, estuarine, and marine sediments in Thailand. Mar. Pollut. Bull. 52, 942-956.

Bouloubassi, I., Fillaux, J., Saliot, A., 2001. Hydrocarbons in surface sediments from the Changjiang (Yangtze River) Estuary, East China Sea. Mar. Pollut. Bull. 42, 1335-1346.

Budzinski, H., Jones, I., Bellocq, J., Pierard, C., Garrigues, P., 1997. Evaluation of sediment contamination by polycyclic aromatic hydrocarbons in the Gironde estuary. Mar. Chem. 58, 85-97.

Commendatore, M.G., Esteves, J.I., Colombos, J.C., 2000. Hydrocarbons in coastal sediments of Patagonia, Argentina: levels and probable sources. Mar. Pollut. Bull. 40, 989-998.

Commendatore, M.G., Nievas, M.L., Amin, O., Esteves, J.L., 2012. Sources and distribution of aliphatic and polyaromatic hydrocarbons in coastal sediments from the Ushuaia Bay (Tierra del Fuego, Patagonia, Argentina). Mar. Environ. Res. 74, $20-31$.

Didky, B.M., Simoneit, B.R.T., Pezoa, L.A., Riveros, M.L., Flores, A.A., 2000. Urban aerosol particles of Santiago, Chile: organic content and molecular characterization. Atmos. Environ. 34, 1167-1179.

Doskey, P.V., 2001. Spatial variations and chronologies of aliphatic hydrocarbons in Lake Michigan sediments. Environ. Sci. Technol. 35, 247-254.

Fernandes, M.B., Sicre, M.A., Boireau, A., Tronczynski, J., 1997. Polyaromatic hydrocarbon (PAH) distributions in the Seine River and its estuary. Mar. Pollut. Bull. 34, 857-867.

Guo, W., He, M., Yang, Z., Lin, C., Quan, X., Wang, H., 2007. Distribution of polycyclic aromatic hydrocarbons in water, suspended particulate matter and sediment from Daliao River watershed, China. Chemosphere 68, 93-104.

Harji, R.R., Yvenat, A., Bhosle, N.B., 2008. Sources of hydrocarbons in sediments of the Mandovi estuary and the Marmugoa harbour, west coast of India. Environ. Int. 34, 959-965.

Hezhong, Y., Enlou, Z., Qi, L., Rong, W., Enfeng, L., 2016. Sources appointment and ecological risk assessment of polycyclic aromatic hydrocarbons (PAHs) in sediments of Erhai Lake, a low-latitude and high-altitude lake in southwest china. Environ. Sci. Pollut. Res. 47, 1-12.

Hu, N.J., Shi, X.F., Liu, J.H., Huang, P., Liu, Y.G., Liu, Y., 2010. Concentrations and possible sources of PAHs in sediments from Bohai Bay and adjacent shelf. Environ. Earth Sci. 60, 1771-1782.

Hu, N.J., Guo, Z.G., Shi, X.F., Qian, Y.W., Lei, K., Zhang, G., 2011. Temporal trends of aliphatic and polyaromatic hydrocarbons in the Bohai Sea, China: evidence from the sedimentary record. Org. Geochem. 42, 1181-1193.

Hu, L.M., Shi, X.F., Lin, T., Guo, Z.G., Yang, Z.S., 2014. Perylene in surface sediments from the estuarine-inner shelf of the East China Sea: A potential indicator to assess the sediment footprint of large river influence. Cont. Shelf Res. 42 (90), 142-150.

Hui, Y.M., Zheng, M.H., Liu, Z.T., Gao, L.R., 2009. Distribution of polycyclic aromatic hydrocarbons in sediments from Yellow River Estuary and Yangtze River Estuary, China. J. Environ. Sci. 21, 1625-1631.

Li, Y., Liu, J., Cao, Z., Lin, C., Yang, Z., 2010. Spatial distribution and health risk of heavy metals and PAHs in the water of the Luanhe River Basin, China. Environ. Monit. Assess. 163, 1-13.

Lin, T., Ye, S.Y., Ma, C.L., Ding, X.G., Brix, H., Yuan, H.M., Chen, Y.J., Guo, Z.G., 2013. Sources and preservation of organic matter in soils of the wetlands in the Liaohe (Liao River) Delta, North China. Mar. Pollut. Bull. 71, 276-285.

Liu, Z.F., Lang, Y.H., Cao, Z.M., Ma, Q.M., 2008. Source apportionment of PAHs in estuarine sediments from the Yellow River. Res. Environ. Sci. 21, $79-84$ (In Chinese).

Liu, A.X., Lang, Y.H., Xue, L.D., Liu, J., 2009. Ecological risk analysis of polycyclic aromatic hydrocarbons (PAHs) in surface sediments from Laizhou Bay. Environ. Monit. Assess. 159, 429-436.

Long, E.R., MacDonald, D.D., Smith, S.L., Calder, F.D., 1995. Incidence of adverse biological effects within ranges of chemical concentrations in marine and estuarine sediments. Environ. Manag. 19, 81-97.

Long, E.R., Field, L.J., MacDonald, D.D., 1998. Predicting toxicity in marine sediments with numerical sediment quality guidelines. Environ. Toxicol. Chem. 17, 714-727.

Long, E.R., Ingersoll, C.G., MacDonald, D.D., 2006. Calculation and uses of mean sediment quality guideline quotient, a critical review. Environ. Sci. Technol. 40, 1726-1736.

Luo, X.J., Chen, S.J., Mai, B.X., Yang, Q.S., Sheng, G.Y., 2006. Polycyclic aromatic hydrocarbons in suspended particulate matter and sediments from the Pearl River Estuary and adjacent coastal areas, China. Environ. Pollut 139, 9-20.

Mai, B.X., Fu, J.M., Sheng, G.Y., Kang, Y.H., Lin, Z., Zhang, G., Min, Y.S., Zeng, E.Y., 2002. Chlorinated and polycyclic aromatic hydrocarbons in riverine and estuarine sediments from Pearl River Delta China. Environ. Pollut. 117, 457-474.

Malik, A., Verma, P., Singh, A.K., Singh, K.P., 2011. Distribution of polycyclic aromatic hydrocarbons in water and bed sediments of the Gomti River, India. Environ. Monit. Assess. 172, 529-545.

Mayer, L.M., 1994. Surface area control of organic carbon accumulation in continental shelf sediments. Geochim. Cosmochim. Acta 58, 1271-1284.

Mille, G., Asia, L., Guiliano, M., Malleret, L., Doumenq, P., 2007. Hydrocarbons in coastal sediments from the Mediterranean Sea (Gulf of Fos area, France). Mar. Pollut. Bull. 54, 566-575.

Mitra, S., Bianchi, T.S., 2003. A preliminary assessment of polycyclic aromatic hydrocarbon distributions in the lower Mississippi River and Gulf of Mexico. Mar. Chem. 82, 273-288.

Oren, A., Aizenshtat, Z., Chefetz, B., 2006. Persistent organic pollutants and sedimentary organic matter properties: a case study in the Kishon River, Israel. Mar. Chem. 141, 265-274.

Ou, D.N., Liu, M., Xu, S.Y., Cheng, S.B., Hou, L.J., Wang, L.L., 2009. Distribution and ecological risk assessment of polycyclic aromatic hydrocarbons in overlying waters and surface sediments from the Yangtze estuarine and coastal areas. Environ. Sci. 30, 3033-3049 (In Chinese).

Pang, X., Li, M., Li, S., Jin, Z., 2003. Geochemistry of petroleum systems in the Niuzhuang South Slope of Bohai Bay Basin. Part 2: evidence for significant contribution of mature source rocks to "immature oils" in the Bamianhe field. Org. Geochem. 34, 931-950.

Pearson, A., Eglinton, T.I., 2000. The origin of $n$-alkanes in Santa Monica Basin surface sediment: a model based on compound-specific $\Delta^{14} \mathrm{C}$ and $\delta^{13} \mathrm{C}$ data. Org. Geochem. 31 (11), 1103-1116.

Peters, K.E., Walters, C.C., Moldowan, J.M., 2005. The Biomarker Guide, Biomarkers and Isotopes in Petroleum Exploration and Earth History, 2nd ed. Vol. 2 Cambridge University Press, UK 700 pp.

Philp, R.P., Fan, Z., 1987. Geochemical investigation of oils and source rocks from Qianjing Depression of Jianhan Basin, a terrigenous saline basin, China. Org. Geochem. 11, 549-562.

Pichler, M., Guggenburger, G., Hartmann, R., Zech, W., 1996. Polycyclic aromatic hydrocarbons (PAH) in different forest humus types. Environ. Sci. Pollut. Res. 3 (1), 24-31.

Prahl, F.G., Ertel, J.R., Goni, M.A., Sparrow, M.A., Eversmeyer, B., 1994. Terrestrial organic carbon contributions to sediments on the Washington margin. Geochim. Cosmochim. Acta 58, 3035-3048.

Qiao, M., Wang, C., Huang, S., Wang, D., Wang, Z., 2006. Composition, sources, and potential toxicological significance of PAHs in the surface sediments of the Meiliang Bay, Taihu Lake, China. Environ. Int. 32, 28-33.

Quiroz, R., Grimalt, J.O., Fernandez, P., 2010. Toxicity assessment of polycyclic aromatic hydrocarbons in sediments from European high mountain lakes. Ecotoxicol. Environ. Saf. 73, 559-564.

Rahmanpoor, S., Ghafourian, H., Hashtroudi, S.M., Bastami, K.D., 2014. Distribution and sources of polycyclic aromatic hydrocarbons in surface sediments of the Hormuz strait, Persian Gulf. Mar. Pollut. Bull. 78, 224-229.

Rodrigo, S.V., William, O.D., Martha, D., Marta, S., 2016. Presence of PAHs in water and sediments of the Colombian Cauca River during heavy rain episodes, and implications for risk assessment. Sci. Total. Environ 540, 455-465.

Sarria-Villa, R., Ocampo-Duque, W., Páez, M., Schuhmacher, M., 2016. Presence of PAHs in water and sediments of the Colombian Cauca River during heavy rain episodes, and implications for risk assessment. Sci. Total Environ. 540, 455-465.

Shi, Z., Tao, S., Pan, B., Fan, W., He, X.C., Zuo, Q., Wu, S.P., Li, B.G., Cao, J., Liu, W.X., Xu, F.L., Wang, X.J., Shen, W.R., Wong, P.K., 2005. Contamination of rivers in Tianjin, China by polycyclic aromatic hydrocarbons. Environ. Pollut. 134, 97-111.

Silliman, J.E., Meyers, P.A., Eadie, B.J., ValKlump, J., 2001. A hypothesis for the origin of perylene based on its low abundance in sediments of Green Bay, Wisconsin. Chem. Geol. 177, 309-322.

Silva, T.R., Lopes, S.R.P., Spörl, G., Knoppers, B.A., Azevedo, D.A., 2012. Source characterization using molecular distribution and stable carbon isotopic composition of $n$ alkanes in sediment cores from the tropical Mundaú-Manguaba estuarine-lagoon system, Brazil. Org. Geochem. 53, 25-33.

Steinhauer, M.S., Boehm, P.D., 1992. The composition and distribution of saturated and aromatic hydrocarbons in nearshore sediments, river sediments, and coastal peat of Alaskan Beaufort Sea. Mar. Environ. Res. 33, 223-253.

Sun, J.H., Wang, G.L., Chai, Y., Zhang, G., Li, J., Feng, J.L., 2009. Distribution of polycyclic aromatic hydrocarbons (PAHs) in Henan Reach of the Yellow River, Middle China. Ecotoxicol. Environ. Saf. 72, 1614-1624.

Tolosa, I., Bayona, J.M., Albaiés, J., 1996. Aliphatic and polycyclic aromatic hydrocarbons and sulfur/oxygen derivatives in northwestern Mediterranean sediments: spatial and temporal variability, fluxes, and budgets. Environ. Sci. Technol. 30, 2495-2503.

Tolosa, I., Mora, S., Sheikholeslami, M.R., Villeneuve, J.P., Bartocci, J., Cattini, C., 2004 Aliphatic and aromatic hydrocarbons in coastal Caspian Sea sediments. Mar. Pollut. Bull. 48, 44-60.

Venkatesan, M.I., Ruth, E., Rao, P.S., Nath, B.N., Rao, B.R., 2003. Hydrothermal petroleum in the sediments of the Andaman Backarc Basin, Indian Ocean. Appl. Geochem. $18,845-861$.

Viguri, J., Verde, J., Irabien, A., 2002. Environmental assessment of polycyclic aromatic hydrocarbons (PAHs) in surface sediments of the Santander Bay, Northern Spain. Chemosphere 48, 157-165.

Volkman, J.K., Holdsworth, D.G., Neill, G.P., Bavor Jr., H.J., 1992. Identification of natural, anthropogenic and petroleum hydrocarbons in aquatic sediments. Sci. Total Environ. 112, 203-219.

Wang, X.C., Sun, S., Ma, H.Q., Liu, Y., 2006. Sources and distribution of aliphatic and polyaromatic hydrocarbons in sediments of Jiaozhou Bay, Qingdao, China. Mar. Pollut. Bull. 52, 129-138.

Wang, C., Wang, W., He, S., Du, J., Sun, Z., 2011. Sources and distribution of aliphatic and polycyclic aromatic hydrocarbons in Yellow River Delta Nature Reserve, China. Appl. Geochem. 26, 1330-1336.

Wang, Z., Liu, Z., Yang, Y., Li, T., Liu, M., 2012. Distribution of PAHs in tissues of wetland plants and the surrounding sediments in the Chongming wetland, Shanghai, China. Chemosphere 89, 221-227.

Yang, Z.F., Wang, L.L., Niu, J.F., Wang, J.Y., Shen, Z.Y., 2009. Pollution assessment and source identifications of polycyclic aromatic hydrocarbons in sediments of the Yellow River Delta, a newly born wetland in China. Environ. Monit. Assess. 158, 561-571.

Yuan, H., Li, T.G., Ding, X.G., Zhao, G.M., Ye, S.Y., 2014. Distribution, sources and potential toxicological significance of polycyclic aromatic hydrocarbons (PAHs) in surface soils of the Yellow River Delta, China. Mar. Pollut. Bull. 83, 258-264.

Yunker, M.B., Macdonald, R.W., Vingarzan, R., Mitchell, R.H., Goyette, D., Sylvestre, S., 2002. PAHs in the Fraser River basin: a critical appraisal of PAH ratios as indicators of PAH source and composition. Org. Geochem. 33, 489-515. 
Zakaria, M.P., Takada, H., Tsutsumi, S., Ohno, K., Yamada, J., Kouno, E., 2002. Distribution of polycyclic aromatic hydrocarbons (PAHs) in rivers and estuaries in Malaysia: a widespread input of petrogenic PAHs. Environ. Sci. Technol. 36, 1907-1918.

Zhang, Z.L., Hong, H.S., Zhou, J.L., Yu, G., 2004. Phase association of polycyclic aromatic hydrocarbons in the Minjiang River Estuary, China. Sci. Total Environ. 323, 71-86.
Zhang, J., Zhang, L.J., Gong, M.N., 2010. The distribution of hydrocarbons in the surface sediments from the Huanghe Estuary and adjacent area. Acta Oceanol. Sin. 32, 23-30 (In Chinese).

Zhang, K., Liang, B., Wang, J.Z., Gguan, Y.F., Zeng, E.D., 2012. Polycyclic aromatic hydrocarbons in upstream riverine runoff of the Pearl River Delta, China: an assessment of regional input sources. Environ. Pollut. 167, 78-84. 